\title{
Detection, ultrastructure and phylogeny of Sclerorhabditis neotropicalis (Nematoda: Rhabditidae) nematodes associated with the Azteca ant-Cecropia tree symbiosis
}

\author{
Jessica Morera ${ }^{1}$, Geovanny Mora-Pineda ${ }^{2}$, Alejandro Esquivel ${ }^{3}$, Paul Hanson ${ }^{2}$ \\ \& Adrián A. Pinto-Tomás ${ }^{4 *}$ \\ 1. Pharmaceutical Research Institute (INIFAR), University of Costa Rica, San José, Costa Rica; \\ jessica.morera@ucr.ac.cr \\ 2. School of Biology, University of Costa Rica, San José, Costa Rica; morapinedageo@gmail.com, \\ phanson91@gmail.com \\ 3. Nematology Department, National University of Costa Rica, San José, Costa Rica; a.esquivel.hernandez@gmail.com \\ 4. Center for Research in Microscopic Structures (CIEMic), Center for Research in Cell and Molecular Biology, \\ Biochemistry Department, School of Medicine, University of Costa Rica, San José, Costa Rica; \\ adrian.pinto@ucr.ac.cr \\ * Correspondence
}

Recibido 20-III-2017. Corregido 08-IX-2017. Aceptado 04-X-2017.

\begin{abstract}
The nematodes involved in ant-plant symbioses have been poorly studied, creating an area of research that is now receiving increasing attention. One example is Sclerorhabditis neotropicalis that inhabit the nests of Azteca ants in Cecropia trees. The goal of the present study is to increase our knowledge about these organisms and their possible symbiotic relationship with the ants and their host plant. The samples were collected during 2011-2013 in different locations in Costa Rica: Parque Nacional Carara (Puntarenas province), San Pedro de Montes de Oca and Highway 27 (San Jose) and La Selva Biological Station (Sarapiquí, Heredia). We examined 576 internodes from 23 plants, comprising four species of Cecropia (including one non-myrmecophyte) and five Azteca species. S. neotropicalis was found in all but one of the Azteca/Cecropia combinations examined. Queen and worker ants were placed in water in order to dislodge nematodes and the results were largely positive, suggesting that alate queens carry $S$. neotropicalis between trees and that workers carry them between internodes. In addition to transport, preliminary observations suggest that the ants provide masses of scraped parenchyma (possibly fertilized with feces) as a substrate for bacteria upon which the nematodes presumably feed. We also found $S$. neotropicalis associated with Azteca in another myrmecophyte, Cordia alliodora, suggesting that this ant/nematode association is not restricted to Cecropia. SEM photographs of $S$. neotropicalis were provided to supplement the original description of this species, and molecular phylogenetic analyses employing three different markers suggest that Sclerorhabditis forms a well-supported clade of bacteria-feeding nematodes associated with Azteca. Indirect evidence suggests that this is a mutualistic association, but the benefits to the ants remain unknown. Rev. Biol. Trop. 66(1): 368-380. Epub 2018 March 01.
\end{abstract}

Key words: nematodes, symbiosis, electron microscopy, Cecropia, Azteca, Costa Rica.

One of the best-known ant-plant mutualisms occurs between trees in the genus Cecropia (Urticaceae) and certain ant species in the genus Azteca (Formicidae: Dolichoderinae), both genera being restricted to the Neotropics (discounting human introductions of Cecropia). About $80 \%$ of the 61 species of Cecropia have a mutualistic association with ants, principally Azteca (Berg, Franco, \& Rosselli, 2005). The genus Azteca comprises 84 species, all of which are arboreal, but only 13 of these are known to be obligate inhabitants of Cecropia (Longino, 1991b; AntWeb, 2016).

The Cecropia tree provides a nesting site inside the hollow stems and a source of nutrition for the ants in structures called Müllerian 
bodies located at the base of the petioles. These food bodies contain glycogen and lipids, providing a valuable food supply for the ants (Rickson, 1971). Other sources of nutrition include smaller food bodies located on the petioles and near the veins on the undersides of young leaves (Rickson, 1976), and honeydew from mealybugs (Hemiptera: Pseudococcidae) that the ants maintain in their nests (Trimble \& Sagers, 2004). Myrmecophytic species of Cecropia (those that harbor ants) also possess specialized parenchyma lining the inside surface of young internodes, though the exact role of this tissue in the mutualism is still unclear (Valverde \& Hanson, 2011).

The Azteca ants benefit the plant by cutting vegetation that encroaches into the Cecropia tree and by removing insect herbivores (Barnwell, 1967; Janzen, 1969; Schupp, 1986; Agrawal, 1998), although the level of protection depends on the species of Azteca (Longino, 1991a; Trimble \& Sagers, 2004), the size of the ant colony (Rocha \& Bergallo, 1992), the abundance of herbivores (Schupp, 1986), and elevation (Trimble \& Sagers, 2004). Azteca ants also provide Cecropia trees with nitrogen (Sagers, Ginger, \& Evans, 2000; Dejean, Petitclerc, Roux, Orivel, \& Leroy, 2012), and plants colonized by ants grow faster than uncolonized plants (Oliveira et al., 2015).

The stems of myrmecophytic Cecropia species are divided into a series of hollow internodes that are separated from one another by solid partitions (septa) at each node. In young stems, the upper part of each internode has an oval depression (prostoma) where the wall is thinner and through which the colonizing Azteca queen chews a hole in order to enter (Bailey, 1922). Once inside, the queen scrapes plant material over the entrance hole, which eventually closes even more tightly as callus tissue grows over it. The queen thus remains sealed inside the internode and apparently relies primarily on her own body reserves to rear the first brood of workers. Once the first workers emerge and reopen the prostoma, they begin foraging for Müllerian bodies, storing them in the internodes, presumably as food for larvae. As the colony grows the workers chew holes in the septa that separate the internodes (Longino, 1989).

In internodes containing Azteca larvae, it is very common to find large numbers of nematodes inhabiting moist, dark-colored mounds of fine-textured material, which appear to consist primarily of parenchyma that the ants have scraped from the internode walls (Longino, 1991a). In Costa Rica, the most common nematode appears to be Sclerorhabditis neotropicalis (Rhabditidae), which probably feeds on bacteria (Esquivel, Abolafia, Hanson, $\&$ Pinto, 2012). The presence of unidentified nematodes has also been reported in young saplings recently colonized by Azteca queens (Weng, Nishida, Hanson, \& LaPierre, 2007), but little else is known about the nematodes associated with these ants. Recently, bacteriafeeding nematodes (Diploscapter sp. and three new species of Sclerorhabditis) were found associated with another ant-tree mutualism in Southeast Asia, Crematogaster ants (Mymicinae) living in Macaranga trees (Euphorbiaceae) (Maschwitz, Fiala, Dumpert, Hashim, \& Sudhaus, 2016). The authors of this study suggested that the nematodes might be cultivated by the ants in refuse piles, and that they are possibly taken into the pospharyngeal gland of worker ants and then fed to the larvae. Another species in the genus Sclerorhabditis, S. miniata, was recently described by Asghar-Shah and Vaid (2015), but in this case, the nematodes were not associated with insects, as they were isolated from humus and farmyard manure, suggesting that this genus may have a wider distribution than originally thought.

In Costa Rica, there are seven species of Cecropia, five of which harbor Azteca ants (González \& Rodríguez, 2015); only the three most widely distributed species (C. peltata, C. obtusifolia, C. insignis) were included in the present study. The two species lacking ants include $C$. pitteri, endemic to the Isla de Coco, and C. angustifolia $(=C$. polyphlebia), which is restricted to higher elevation cloud forests and was included in the present study. Of the 21 Azteca ant species in the country, 
five are restricted to Cecropia (Longino, 2007). The objectives of the present study were: 1) Determine whether Sclerorhabditis nematodes are associated with the four Cecropia species examined and all five Azteca; 2) Determine whether the presence of Sclerorhabditis nematodes in Cecropia is dependent upon the presence of Azteca; 3) Examine queen and worker ants for the presence of nematodes; and 4) Provide an ultrastructural and molecular phylogenetic analyses of Sclerorhabditis specimens from different samples. We hypothesized that Sclerorhabditis is carried between trees by Azteca queens, and within trees by worker ants, and therefore its presence in Cecropia trees, and in individual internodes, is dependent upon the presence of Azteca.

\section{MATERIALS AND METHODS}

Field collections and sample identifications: Cecropia-Azteca samples and their associated nematodes were collected during 2011-2013 (see Table 1). Cecropia trees were identified utilizing the taxonomic description by Berg \& Franco-Rosselli (2005). Azteca ants were identified by analyzing queens and/or workers, using the taxonomic keys by Longino (1991b, 2007); voucher specimens are deposited in the Zoology Museum at the University of Costa Rica. Slide-mounted nematodes were identified employing relevant taxonomic literature (Andrassy, 1984; Ahmad, Shah, \& Mahamood, 2007; Esquivel et al., 2012).

Examination of individual internodes: Entire plants mostly 1-2 $\mathrm{m}$ in height were collected (cut at the base) from seven sites (Table 1). A total of 23 plants from four Cecropia species, including the non-myrmecophytic $C$. angustifolia, were brought to the laboratory, where a total of 576 internodes were examined. Cuts were made just beneath each node so that each internode contained its base. Each internode was then placed in a petri plate, cut longitudinally, and examined under a dissecting microscope for presence of ants (workers, pupae, larvae) and nematode mounds. Samples of adult ants were preserved in $75 \%$ ethanol, and nematodes in $4 \%$ formaldehyde, for later identification. Nematodes were later transferred to glycerin (Seinhorst, 1959) and mounted on glass slides, utilizing the technique described by De Maeseneer and D'Herde (1963). In addition to Cecropia, qualitative observations were made of Azteca pittieri associated with Cordia alliodora (Boraginaceae) in Santa Rosa National Park (Guanacaste prov.), and $A$. instablis nesting in a mango tree (Mangifera indica, Anacardiaceae) in Bolívar, San Ramón (Alajuela prov.).

Observations of ant/nematode interactions: Ten colonies (including a queen, workers, brood, and nematodes) originating

TABLE 1

Collection sites used for examination of individual internodes, showing number of plants employed of each Cecropia species

\begin{tabular}{|c|c|c|c|c|c|}
\hline Site & Coordinates & C. obtusifolia & C. peltata & C. insignis & C. angustifolia \\
\hline Abangares, GU & $10^{\circ} 16^{\prime} 55^{\prime \prime} \mathrm{N}, 84^{\circ} 57^{\prime} 36^{\prime \prime} \mathrm{W}$ & & 3 & & \\
\hline Bolívar, San Ramón, AL & $10^{\circ} 06^{\prime} 18^{\prime \prime} \mathrm{N}, 84^{\circ} 29^{\prime} 08^{\prime \prime} \mathrm{W}$ & 1 & & & \\
\hline Ciudad Quesada, AL & $10^{\circ} 19^{\prime} 19^{\prime \prime} \mathrm{N}, 84^{\circ} 25^{\prime} 39^{\prime \prime} \mathrm{W}$ & & & 1 & \\
\hline Moravia, SJ & $10^{\circ} 03^{\prime} 45^{\prime \prime} \mathrm{N}, 84^{\circ} 03^{\prime} 54^{\prime \prime} \mathrm{W}$ & & & & 4 \\
\hline Ostional, GU & $09^{\circ} 59^{\prime} 46^{\prime \prime} \mathrm{N}, 85^{\circ} 41^{\prime} 56^{\prime \prime} \mathrm{W}$ & & 3 & & \\
\hline Res.Biol. A. Brenes, AL & $10^{\circ} 13^{\prime} 12^{\prime \prime} \mathrm{N}, 84^{\circ} 36^{\prime} 06^{\prime \prime} \mathrm{W}$ & & & 2 & \\
\hline Santa Elena, AL & $10^{\circ} 13^{\prime} 38^{\prime \prime} \mathrm{N}, 84^{\circ} 51^{\prime} 28^{\prime \prime} \mathrm{W}$ & & 2 & & \\
\hline UCR, San Pedro, SJ & $09^{\circ} 56^{\prime} 15^{\prime \prime} \mathrm{N}, 84^{\circ} 02^{\prime} 57^{\prime \prime} \mathrm{W}$ & 5 & & & \\
\hline UCR, San Ramón, AL & $10^{\circ} 05^{\prime} 04^{\prime \prime} \mathrm{N}, 84^{\circ} 28^{\prime} 43^{\prime \prime} \mathrm{W}$ & 2 & & & \\
\hline
\end{tabular}

Provinces: $\mathrm{GU}=$ Guanacaste, $\mathrm{AL}=$ Alajuela, $\mathrm{SJ}=$ San José. 
from different plants were brought to the laboratory at the University of Costa Rica and maintained in dissected internodes placed on petri plates inside closed plastic containers. These colonies were provided with three to four drops of water per week and with Müllerian bodies (both individually and attached to the petiolar base) from C. obstusifolia growing on campus. Observations of ant/nematode interactions were made for about five minutes, two times per day, twice weekly. If live nematodes were still present when the ant colony died, the former were maintained to observe how long the nematodes survived in the absence of ants. Four additional internodes were maintained with nematodes but without ants.

Detection of nematodes on Azteca bodies: In order to determine whether queens carry nematodes, the following treatments were applied to individuals obtained from the internodes examination. Queens were placed individually in a drop of water in a petri plate for 10 minutes, in order to observe whether nematodes became detached, indicating their presence on the surface of the ant's body. Then, individual queen ants were rinsed in pure water, and dissected into three sections (head, mesosoma, metasoma) with a scalpel; each section was placed in a drop of water in a petri plate for 10 minutes to allow nematodes to exit the body. A total of 63 live queens from various Cecropia and Azteca species were used; all were wingless queens that had recently colonized the internode except for the $11 \mathrm{~A}$. alfari, which were virgin alates (still in their maternal nest), and two of the A. constructor queens, that were encountered on the outside part of the plant, presumably in process of colonization.

Samples of worker ants were obtained from C. obtusifolia in La Selva Biological Station (Heredia prov.) in the Caribbean lowlands, Moravia (San José prov.) in the Central Valley, and C. peltata in Carara National Park (Puntarenas prov.) in the Pacific lowlands. Ants from each locality were sectioned into three parts (head, mesosoma, metasoma), and each part was then immersed in sterile water. The nematodes were counted and homocedasticity was evaluated employing the Levene test (Levene, 1960), as well as the Shapiro-Wilks test (Shapiro \& Wilk, 1965). Means were compared employing the non-parametric Kruskal-Wallis test (Sidney \& Castellan, 1988). Statistical analyses were performed with the SPSS software, version 21 (Brosius, 2013).

Scanning Electron Microscopy (SEM): Because only light microscope photographs are currently available for Sclerorhabditis neotropicalis (Esquivel et al., 2012), we placed special emphasis on the ultrastructural characterization of this recently described species. Ten individual nematodes from a single Cecropia tree from each of the three sampled regions were placed in modified Beem ${ }^{\circledR}$ capsules and processed according to Karnovsky (1965) and Webster, Allison, Ubelaker and Riddle (1971). Samples were covered with a Gold-Paladium layer, employing an Ion sputter (GIKO IB-3, Japan), and observed with a scanning electron microscope (Hitachi S-570, Japan) at $15 \mathrm{Kv}$. Micrographs were taken with a Pentax Digital Camera adapted to the microscope.

Molecular phylogeny of Sclerorhabditis nematodes: We sequenced three genes of taxonomic interest from 18 individuals of Sclerorhabditis collected in Cecropia colonized by Azteca ants from three locations in Costa Rica: La Selva Biological Station, San José (Central Valley) and Carara National Park. Fragments of rRNA 28S, rRNA $12 \mathrm{~S}$ and cytochrome oxidase genes were amplified by polymerase chain reaction employing the primers and conditions described by Stock, Campbell and Nadler (2001). Obtained nucleotide sequences were compared with those available in the NCBI database (National Center for Biotechnology Information) employing BLAST 2.0 (Altschul et al., 1997). For phylogenetic analyses, sequences were aligned with GUIDANCE (Penn et al., 2010) employing the MAFFT algorithm and 100 bootstrap iterations, utilizing the Jukes Cantor Model. Phylogenetic trees were then constructed employing the Bayesian 
method implemented by the MrBayes v.3.0b4 software (Ronquist \& Huelsenbeck, 2003), with a few substitution types equal to one $(\mathrm{nst}=1)$ (Simpson, Helfgott, Weeks, \& Larkin, 2004). Phylogenetic trees were edited with Fig Tree v1.4.0, MEGA 6 (Tamura, Dudley, \& Kumar, 2007) and Adobe Illustrator CS5.

\section{RESULTS}

Examination of individual internodes: A total of 576 internodes were analyzed from four species of Cecropia: 243 from C. peltata, 141 from C. obtusifolia, 100 from C. angustifolia, and 92 from C. insignis (Fig. 1). Of the 23 plants analyzed only one $C$. angustifolia and one $C$. peltata lacked Azteca. Of the 576 internodes, 226 were inhabited by at least one of the five Azteca species and were distributed as follows: $72(12.5 \%)$ internodes with $A$. xanthochroa, $57(9.9 \%)$ with A. coeruleipennis, 44 (7.6 \%) with A. constructor, 30 (5.2\%) with $A$. ovaticeps and 23 (4\%) with A. alfari. The Azteca-free internodes consisted of 110 (19.1\%) showing evidence of previous occupation by Azteca (open prostoma, hole in nodal wall, dead Azteca), and 240 (41.7 \%) showing no evidence of previous occupation.

Of the different combinations of Azteca and Cecropia observed in this study (Fig. 1), Sclerorhabditis nematodes were present in all except A. xanthochroa / C. obtusifolia. These nematodes were present at all sites (Table 1) except for the Reserva Biológica Alberto Brenes. Nematodes were found in 103 internodes, 96 of which also contained Azteca ants, and this relationship was significant (Fig. 2).

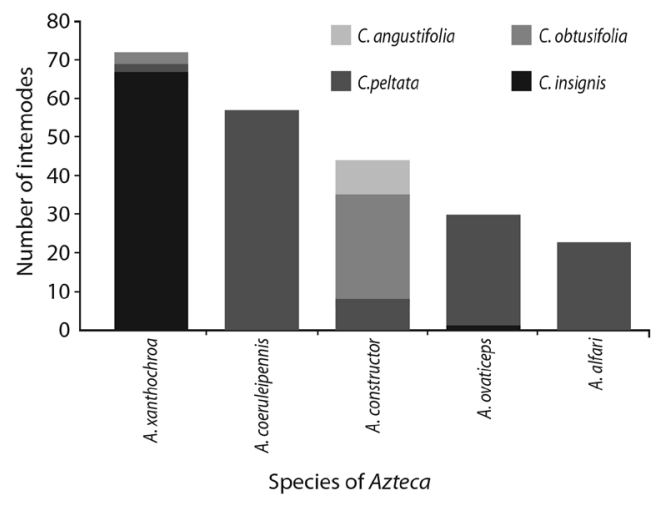

Fig. 1. Number of internodes of four species of Cecropia inhabited by five Azteca species.

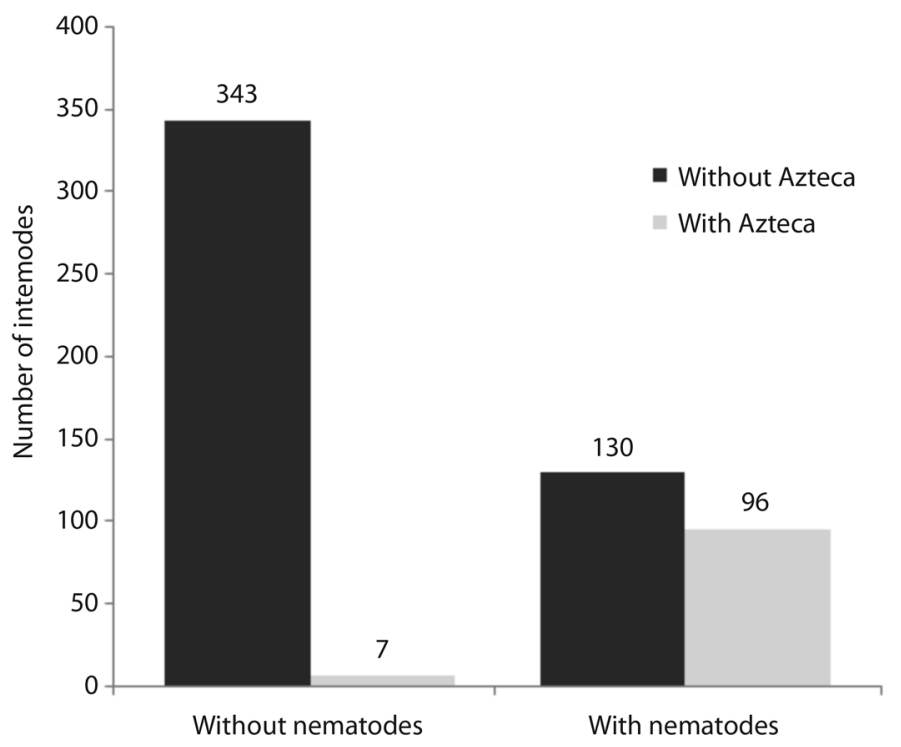

Fig. 2. Number of Cecropia internodes with and without nematodes in relation to presence/absence of Azteca $(n=576, X 2=153, p<0.001)$. 
Of the 103 internodes with nematodes, 79 (76 $\%)$ were identified as being Sclerorhabditis; the remaining internodes contained other Rhabditidae, mostly Diploscapter. No nematodes were found in any of the 240 internodes that showed no evidence of previous occupation by Azteca. The percentage of internodes harboring Sclerorhabditis for each species of Azteca was as follows: $59 \%$ for $A$. constructor, $43 \%$ for A. alfari and A. xanthochroa, $42 \%$ for A. coeruleipennis, and $20 \%$ for $A$. ovaticeps. Only 2 $\%$ of the empty internodes, but with evidence of previous occupation by Azteca, contained Sclerorhabditis. The percentage of internodes harboring Sclerorhabditis for each species of Cecropia was as follows: $29 \%$ for C. insignis, $20 \%$ for C. peltata, $16 \%$ for C. obtusifolia, and $5 \%$ for $C$. angustifolia. In Cordia alliodora, Sclerorhabditis was found in domatia occupied by Azteca pittieri, but not in domatia occupied by another ant symbiont, Zacryptocerus setulifer. In an A. instabilis nest occupying a tree hole on mango, a dark humid mass containing nematodes (similar to that seen in Cecropia) was observed, but Sclerorhabditis was not found.

Observations of ant/nematode interactions: Of the ten Azteca colonies brought to the laboratory (four A. constructor, two $A$. coeruleipennis, three $A$. xanthochroa and one A. ovaticeps), three colonies died within the first three days. Of the remainder, three colonies of $A$. constructor were maintained for two weeks; two colonies of $A$. coeruleipennis, one of $A$. xanthochroa and one of $A$. ovaticeps were maintained for more than a month. In colonies that were maintained for more than a month, a slight increase in the number of workers was observed, though all colonies eventually died. The death of the colonies was associated with a decrease in the number of Müllerian bodies that we could provide; the queen was always the last to die and in one case, the queen survived for 22 days without food. On $80 \%$ of the occasions when a drop of water was added, worker ants surrounded the drop, from which they appeared to be drinking.
After the colonies died, the nematodes were maintained in the same containers, and in all ten cases, the nematodes remained alive for more than a month. The nematodes from the A. xanthochroa colony remained alive for two months after the death of the queen. It is worth noting that while the ant colony remained alive the nematodes were found only in the dark humid mass, but when the workers died, the nematodes dispersed throughout the provided piece of Cecropia.

A total of 50 observations were made, 5 minutes each, but no regular behavioral patterns were noted with respect to the nematode masses. The ant/nematode interactions consisted almost exclusively (99\%) of ants occasionally walking over the nematode mass. However, two behaviors observed in one occasion each are noteworthy: 1) a worker of $A$. xanthochroa stopped on top of the nematode mass, curved its abdomen downward and deposited a drop of brown liquid (possibly feces); 2) in the same colony, a piece of parenchyma found in a water droplet we provided was carried by a worker to the nematode mass.

Detection of nematodes on Azteca bodies: Of the 63 queens that were placed in water, 29 (46\%) had nematodes and 25 of these were identified as Sclerorhabditis. In six cases, the queens came from internodes lacking a nematode mass and thus the queen's body was the only place where nematodes were found. The two $A$. constructor queens captured on the outside of C. obtusifolia (in process of colonizing) were found to be carrying Sclerorhabditis. From the previous group of queens, 32 were subsequently placed in water with detergent, and nematodes were found in 11, including the two A. constructor queens mentioned previously. Of the 28 queens that were dissected, nematodes were found in the metasoma of 9 , the mesosoma of 7, and the head of 4 . The greatest number of nematodes were found in the metasoma, up to 18 , whereas the head and mesosoma had from 1 to 4 nematodes each.

Among worker ants, nematodes were found primarily on the mesosoma, including 
the legs. Almost none of the nematodes were obtained from head and metasoma sections, and we found a statistically significant difference $(P=0.001)$ in the average number of nematodes recovered from the mesosoma (between one and three), when compared to the other body sections (average close to zero). We did not find statistically significant differences between the average number of nematodes recovered from the head and metasoma sections ( $\mathrm{P}=0.667)$. These results were consistent across the three geographic regions sampled within Costa Rica (Fig. 3).

Among the different sampled sites, Carara National Park in the Pacific lowlands and La Selva Biological Station in the Caribbean lowlands had a significantly higher number of nematodes recovered from Azteca workers when compared to the Central Valley region $(\mathrm{P}=0.001)$. However, there was no statistically significant difference between the number of nematodes recovered from ant workers obtained in Carara and La Selva $(\mathrm{P}=0.215)$.

\section{Scanning Electron Microscopy:} Sclerorhabditis adults ranged in length from $315 \mu \mathrm{m}$ to $532 \mu \mathrm{m}$, and showed a sclerotized, crown-shaped labial region, results that are consistent with the description provided previously (Fig. 4). The main morphological characteristics analyzed by scanning electron microscopy are shown in Fig. 5. The cuticular annulation is regular along the entire body and each annulus is forked just behind each lateral line; this characteristic was not seen under the light microscope. The lateral fields are composed of two coarse lines, as described before; however, between the two lateral lines the cuticle looks smooth. The lips in frontal view confirm the complex structure described, with three curved thorn-shaped projections directed towards the stoma, the central one longer, wider and tongue-shaped. The lateral lips are hyaline, membranous, and square-shaped (Fig. 5). The vulva and anus are transverse slits.

Molecular phylogeny of Sclerorhabditis nematodes: Our phylogenetic analyses with Sclerorhabditis specimens isolated from the Cecropia-Azteca symbiosis were based on seven successfully obtained sequences for the 28S rRNA and seven sequences for the $12 \mathrm{~S}$ rRNA genes, as well as four sequences for the cytochrome oxidase gene. Individual phylogenetic trees were constructed for each gene, obtaining similarly consistent

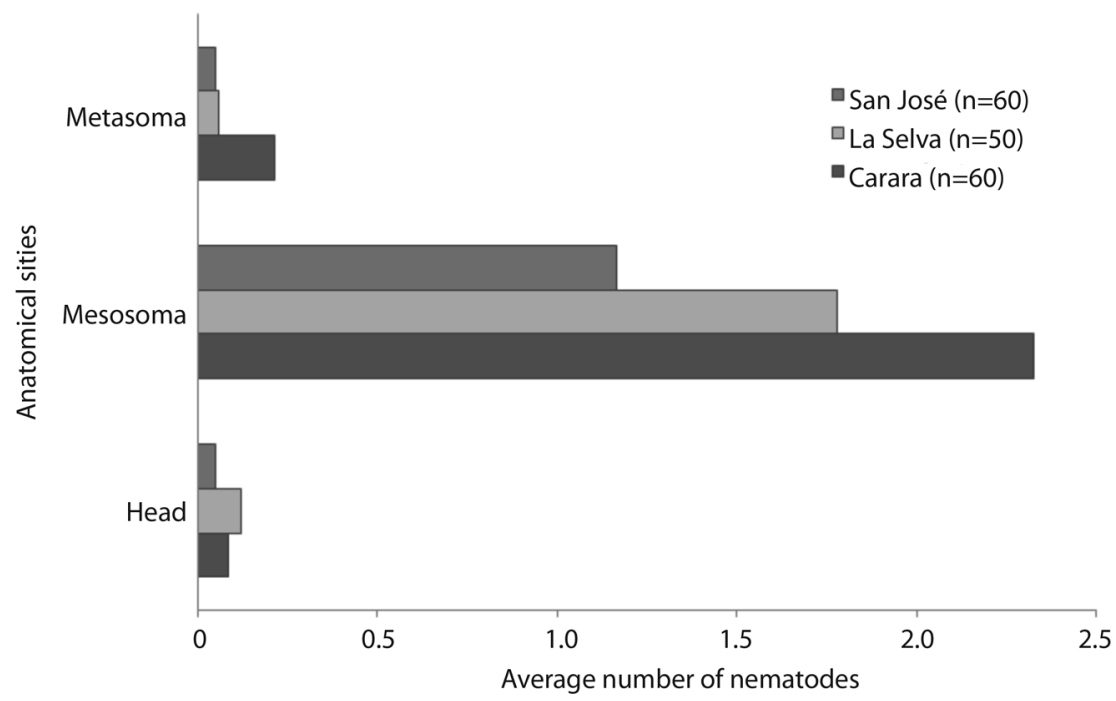

Fig. 3. Average number of nematodes recovered from different anatomical sites of Azteca ant workers across different locations in Costa Rica. 


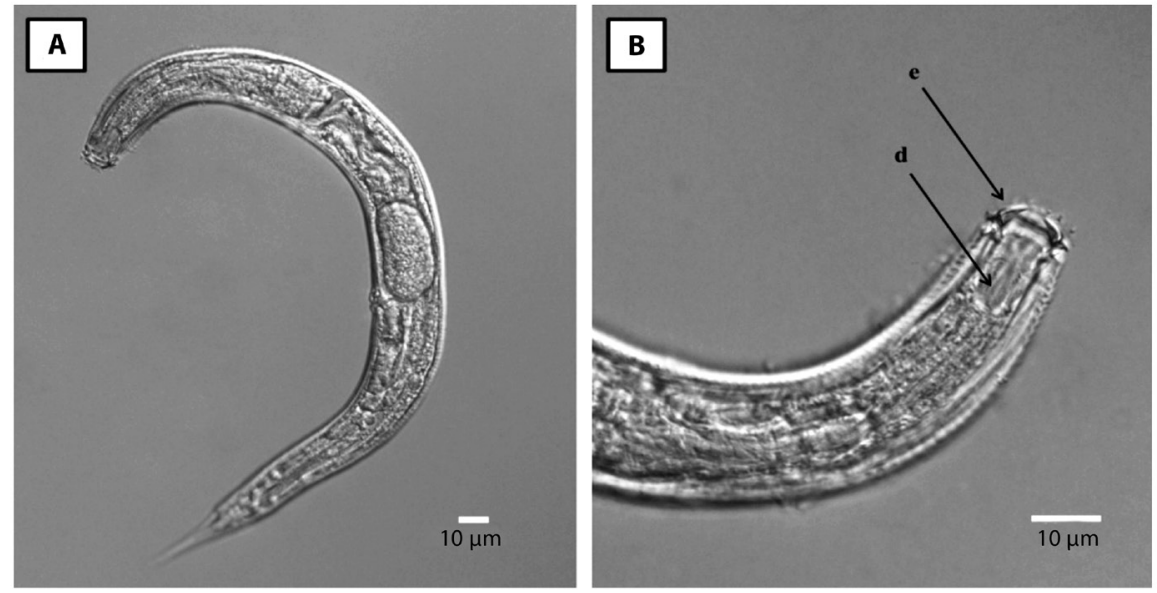

Fig. 4. Light microscope photograph of adult Sclerorhabditis obtained from C. obtusifolia in San José, Costa Rica. A) Complete body. B) Detail of the lip region (e) and stoma (d).
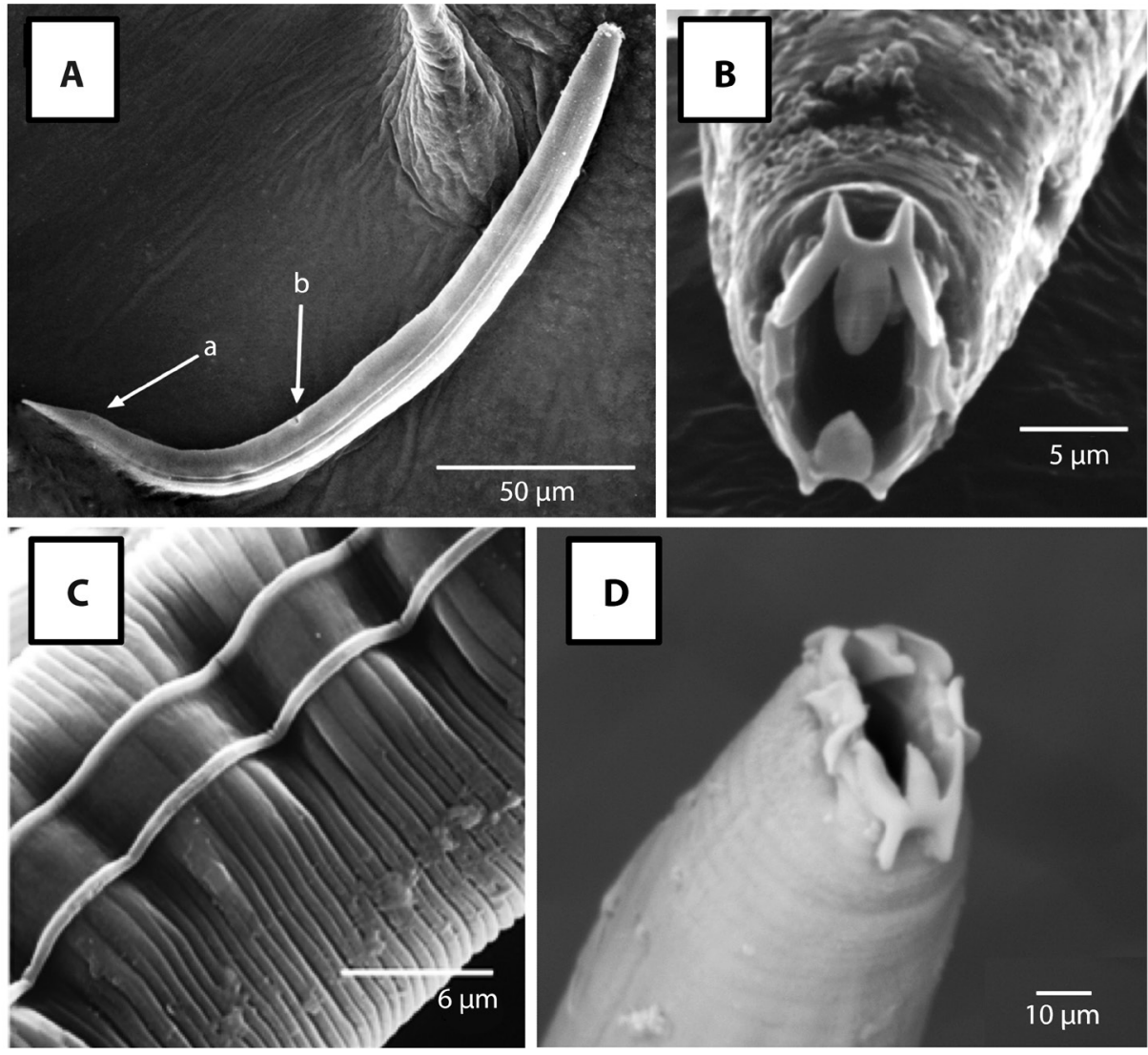

Fig. 5. SEM micrograph of Sclerorhabditis specimens collected in C. obtusifolia from Carara National Park. A) Whole body mount, indicating lateral lines, anus (a) and vulva (b); B) Close-up of the oral region; C) Detail of the cuticle; D) Detail of lateral lips. 
results. All Sclerorhabditis sequences grouped together in a well-supported clade, regardless of their geographic origin or the species of their Cecropia-Azteca hosts. The sequences from other nematodes belonging to the family Rhabditidae also grouped together. The most divergent Sclerorhabditis sequence originated from a nematode recovered from a C. obtusifolia tree sampled at Carara National Park. The sister clade of Sclerorhabditis in our analyses consists of Diploscapter and Protorhabditis specimens (Fig. 6). Nucleotide sequences were deposited at GenBank under accession numbers KT456622-KT456628.

\section{DISCUSSION}

The results from our examination of individual internodes showed that nematodes occur only in those plants and internodes that harbor (or once harbored) Azteca ants. The two plants that lacked nematodes also lacked Azteca: one C. peltata, which was very small $(0.4 \mathrm{~m})$ and lacked Müllerian bodies, and one $C$. angustifolia. In Costa Rica, the latter species lacks adaptations for harboring ants and never contains Azteca colonies, although queens often attempt to colonize this Cecropia (Longino, 1989), which was the case in those plants where nematodes were found. The internodes harboring Azteca, but without nematodes may be explained, at least in part, by the difficulty of detecting nematodes with the dissecting microscope. Unless the nematodes are moving, they are nearly impossible to observe.

Sclerorhabditis neotropicalis was found in all Azteca-Cecropia combinations, except in the A. xanthochroa / C. obtusifolia combination.

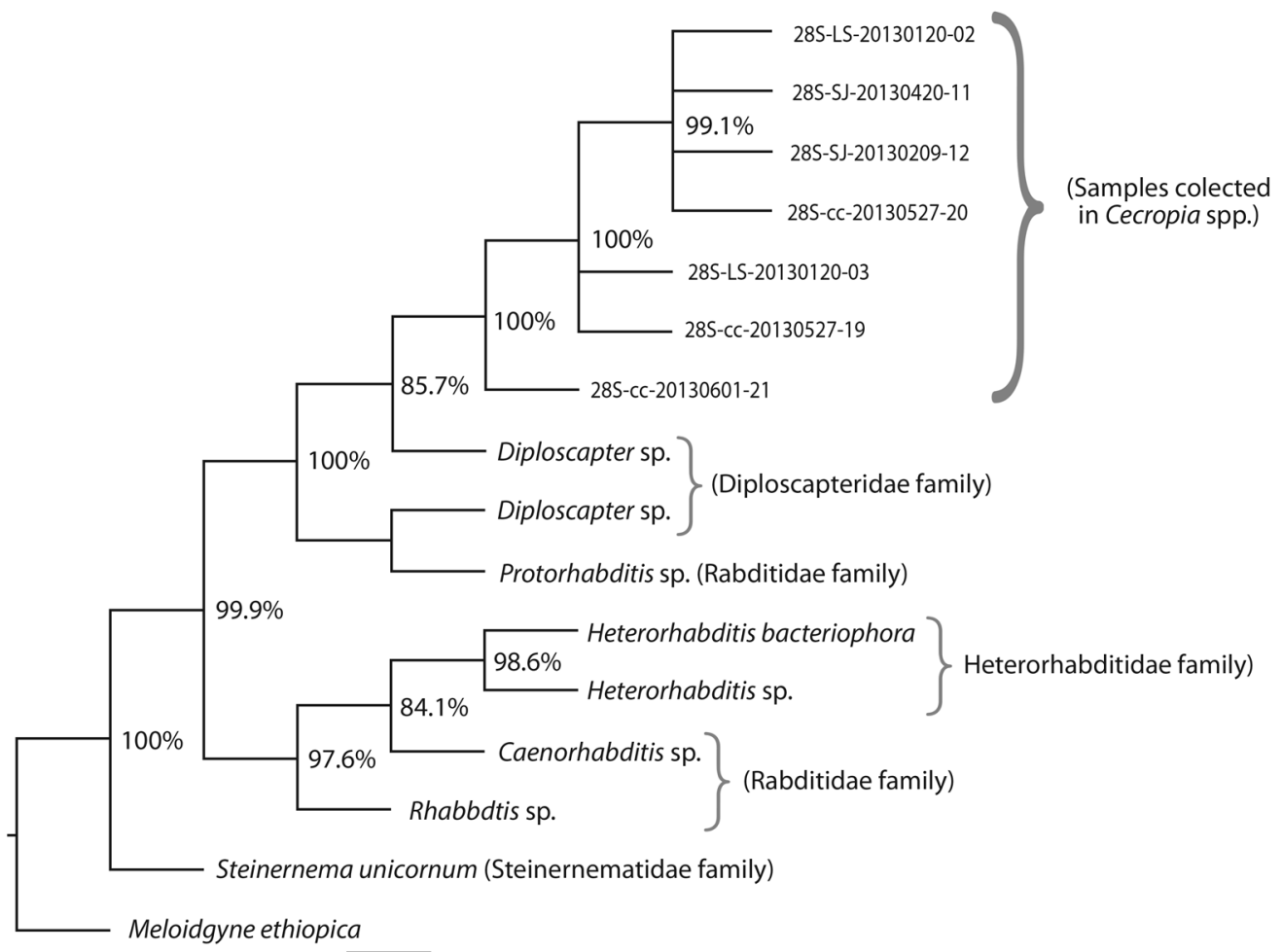

0.9

Fig. 6. Phylogenetic tree constructed with sequences coding for the $28 \mathrm{~S}$ rRNA gene of Sclerorhabditis nematodes isolated from Cecropia spp. Each individual code indicates the geographic origin and date of collection. The numbers at tree branches represent posterior probabilities calculated by the Bayesian method. M. ethiopica was employed as outgroup (Order Tylenchida). LS = La Selva Biological Station; SJ = San Jose; cc = Carara National Park. 
Other unidentified nematodes were found in this combination and it is likely that the absence of Sclerorhabditis is due to the small number (three) of internodes analyzed with this combination. It should be noted that we did not find all the possible Azteca / Cecropia combinations that have been reported in Costa Rica (Longino, 1989), but we predict that $S$. neotropicalis will be found in those combinations that were not examined here. Similar studies are needed in other Neotropical countries, to determine the geographic distribution of $S$. neotropicalis and its prevalence in other Azteca / Cecropia combinations.

One of the most interesting results of the present study was finding $S$. neotropicalis in Cordia alliodora, where the nematodes were associated with Azteca pittieri, but not with the other ant symbiont, Zacryptocerus setulifer. Because of the small sample size, this result requires confirmation, but if true, it would suggest that $S$. neotropicalis has a wider association with Azteca species, beyond those that inhabit Cecropia. It would be especially worthwhile examining Azteca species that do not live in myrmecophytic plants. For example, although we observed nematode masses associated with $A$. instabilis in a mango tree, we did not find Sclerorhabditis; however, this was just a cursory examination.

It is also noteworthy that we never found nematodes in internodes that had never been occupied by Azteca. This result agrees with our observations of nematodes on the bodies of ants, namely that both queens and workers carry nematodes, which would explain how the nematodes colonize Cecropia plants (on queens) and how they move from one internode to another (on workers, possibly on the legs). However, more detailed studies are required to determine whether nematodes are carried in specific locations on (or in) the body, whether queens and workers differ in this regard, and the nematode stages involved in transport.

As is known for other Rhabditidae associated with ants (Poinar, 2012), there seems to be little doubt that Azteca ants do indeed transport Sclerorhabditis and that there are ample opportunities for this to occur. The moist mass of fine-textured material (probably parenchyma scraped from the internode by the ants) contains very large numbers of nematodes (in one mass we estimated about 22000 ) and the surface of this mass is generally writhing with nematodes. The movements of Sclerorhabditis in the nematode masses seem to comply with the definition of nictation (standing on their tail and waving), a behavior that serves in finding a host (Brown, D'Anna, \& Sommer, 2011), or in this case, a means of transport.

The presence of nematodes in some internodes that lacked Azteca, but showed evidence of previous Azteca occupation, is consistent with our finding that the nematodes can survive for about a month in the absence of the ants. On the other hand, our preliminary observations suggest that the nematodes cannot survive for much longer in the absence of the ants, but this requires further study. If this is indeed the case, it leads to the question of what it is that the ants are providing for the nematodes (in addition to transport). Based on our preliminary observations we suggest that, at a minimum, the ants provide scraped parenchyma and feces, which in turn support the bacteria on which the nematodes feed. However, research is needed both to substantiate these observations and to identify the bacteria (and other microorganisms) present in the nematode masses.

Among this apparent nematode diversity, we decided to concentrate our efforts in characterizing specimens from the newly described species Sclerorhabditis neotropicalis employing both scanning electron microscopy and phylogenetic analyses. The ultrastructural description of $S$. neotropicalis individuals is congruent and complements the current knowledge of this genus (Ahmad et al., 2007) and species (Esquivel et al., 2012), as these tools allow for a more detailed and higher resolution observation of the nematode cuticle and external structures, as highlighted in the results section (Jesús-Navarrete, 1991). Furthermore, the results obtained in our phylogenetic analyses employing different taxonomic markers were consistent with each other and suggest that the 
recovered Sclerorhabditis specimens form a well-supported clade of bacteria-feeding nematodes associated with the Cecropia-Azteca symbiosis within the family Rhabditidae.

Perhaps the most interesting unanswered question is whether the Azteca/Sclerorhabditis symbiosis is mutualistic or commensalistic. There seems little doubt that the nematodes benefit from the association but what, if anything, the ants gain is unknown. The fact that the nematode masses invariably occur in the same internodes as the ant brood suggests that they are important for the ants. Moreover, our preliminary observations suggest that the ants cultivate the presumed bacterial food source of the nematodes, by providing mounds of scraped parenchyma fertilized with feces, though a more detailed study is required to substantiate this suggestion.

It would be worthwhile examining whether nitrogen derived from the nematodes ends up in ant larvae and/or in the plant. Finally, more research is needed to determine the frequency of other nematodes (e.g. Diploscapter) in Azteca nests, and their role as compared with that of Sclerorhabditis.

\section{ACKNOWLEDGMENTS}

This work was supported by grant VI801-B0-538 from the Vicerrectoría de Investigación at the University of Costa Rica. The authors wish to express their gratitude to the Pharmaceutical Research Institute (INIFAR) for its support to J.M., Idea Wild for its support to G.M.-P., Elizabeth Pringle for samples from Cordia alliodora, as well as the Biodiversity Institutional Commission of the University of Costa Rica and the Ministry of Environment and Energy (MINAE, Costa Rican Government) for providing biodiversity access and collection permits.

\section{RESUMEN}

Detección, ultraestructura y filogenia de los nemátodos Sclerorhabditis neotropicalis (Nematoda: Rhabditidae) asociados con la simbiosis de la hormiga Azteca y el árbol Cecropia. Los nemátodos asociados a la simbiosis entre plantas y hormigas han sido poco estudiados, creando un área de investigación que está recibiendo cada vez más atención. Un ejemplo de esto es Sclerorhabditis neotropicalis, que habita en los nidos de las hormigas Azteca asociadas a árboles de Cecropia. El objetivo de este trabajo es incrementar el conocimiento sobre esta especie de nemátodo y su relación con Azteca-Cecropia. Las muestras fueron recolectadas durante 2011-2013 en diferentes localidades de Costa Rica: Parque Nacional Carara (Puntarenas), San Pedro de Montes de Oca y Ruta 27 (San José) y la Estación Biológica La Selva (Sarapiquí, Heredia). Se examinaron 576 entrenudos de 23 plantas, comprendiendo cuatro especies de Cecropia (incluyendo una especie no mirmecófita) y cinco especies de Azteca. Se encontraron individuos de $S$. neotropicalis en todas las combinaciones de Azteca/Cecropia examinadas. Las hormigas reinas y trabajadoras fueron colocadas en agua para observar los nematodos y los resultados fueron en gran medida positivos, lo cual sugiere que las reinas aladas transportan S. neotropicalis hacia nuevos árboles y que las trabajadoras los transportan entre los entrenudos. Además del transporte, las observaciones preliminares insinúan que las hormigas proporcionan una masa de parénquima raspado (posiblemente fertilizado con heces) como sustrato para bacterias que luego servirán de alimento a los nematodos. Adicionalmente, encontramos S. neotropicalis asociado con Azteca en otro tipo de árbol, Cordia alliodora, sugiriendo que esta asociación de hormigas/nematodos no se limita a Cecropia. Las fotografías de microscopía electrónica de $S$. neotropicalis obtenidas en este trabajo complementan la descripción original de esta especie. Por otra parte, los análisis filogenéticos moleculares sugieren que Sclerorhabditis forma un clado bien definido de nematodos bacteriófagos asociados con Azteca. La evidencia indirecta apunta a que se trata de una asociación mutualista, pero los beneficios para las hormigas siguen siendo desconocidos.

Palabras clave: simbiosis, microscopia electrónica, Cecropia, Azteca, Costa Rica.

\section{REFERENCES}

Agrawal, A. (1998). Leaf damage and associated cues induce aggressive ant recruitment in a neotropical ant-plant. Ecology, 79, 2100-2112.

Ahmad, I., Shah, A., \& Mahamood, M. (2007). Nematodes of the order Rhabditida from India. Description of Sclerorhabditis tridentatus gen. n., sp. n. (Nematoda: Rhabditidae). Journal of Nematology, 9(1), 43-47.

Altschul, S. F., Madden, T. L., Schäffer, A., Zhang, J., Zhang, Z., Miller, W., \& Lipman, D. J. (1997). Gapped BLAST and PSI-BLAST: a new generation of protein database search programs. Nucleic Acid Research, 25, 3389-3402. 
Andrássy, I. (1984). Klasse Nematoda (Ordnungen Monhysterida, Desmoscolecida, Araeolaimida, Chromadorida, Rhabditida). Stuttgart: Fischer.

Antweb. (2016). The California Academy of Sciences, San Francisco, U.S.A. https://www.antweb.org/description.do?subfamily $=$ dolichoderinae $\&$ genus $=$ azteca $\& r$ ank=genus\&project=allantwebants

Asghar-Shah, A., \& Vaid, S. (2015). Description of Sclerorhabditis miniata $\mathrm{n}$. sp. and first description of male of Diploscapter coronatus Cobb, 1913 (Nematoda: Rhabditidae). Journal of Nematology, 47(2), 153-158.

Bailey, I. W. (1922). Notes on Neotropical ant-plants I. Cecropia angulata, sp. nov. Botanical Gazette, 74, 369-391.

Barnwell, F. H. (1967). Daily patterns in the activity of the arboreal ant Azteca alfari. Journal of Ecology, $48,991-993$.

Berg, C. C. \& Franco-Rosselli, P. (2005). Cecropia. Flora Neotrpica, 94, 1-230.

Brosius, F. (2013). SPSS 21. MITP-Verlags GmbH \& Co. KG.

Brown, F. D., D’Anna, I., \& Sommer, R. J. (2011). Hostfinding behavior in the nematode Pristionchus pacificus. Proceedings of the Royal Society of London B: Biological Sciences, 278, 3260-3269.

De Maeseneer, J., \& D’Herde, J. (1963). Méthodes utilisées pour l'étude des anguillules libres du sol. Revue Agriculture Bruxelles, 16, 441-447.

Dejean, A., Petitclerc, F., Roux, O., Orivel, J., \& Leroy, C. (2012). Does exogenic food benefit both partners in an ant-plant mutualism? The case of Cecropia obtusa and its guest Azteca plant-ants. Comptes Renus Biologies, 335, 214-219.

Esquivel, A., Abolafia, J., Hanson, P., \& Pinto, A. (2012). A new species of nematode, Sclerorhabditis neotropicalis sp. n. (Rhabditida), associated with Azteca ants in Cecropia obtusifolia. Nematropica, 42(1), 163-169.

González, J., \& Rodríguez, A. (2015). Cecropia. In: Hammel B E, Grayum M H, Herrera C, Zamora N (Eds.), Manual de Plantas de Costa Rica, Volumen VIII, Dicotiledóneas (Sabiaceae-Zygophyllaceae) (pp. 473-479). St. Louis: Missouri Botanical Garden Press.

Janzen, D. H. (1969). Allelopathy by myrmecophytes: the ant Azteca as an allelopathic agent of Cecropia. Ecology, 50, 147-153.

Jesús-Navarrete, A. (1991). Nemátodos marinos y la actividad petrolera en la Sonda de Campeche. Congreso de Ciencias del Mar, Marcuba.
Karnovsky, M. J. (1965). A formaldehyde-glutaraldehyde fixative of high osmolarity for use in electron microscopy. Journal of Cell Biology, 27, 137.

Levene, T. (1960). Robust tests for equality of variances. In Okin (Ed.), Contributions to Probability and Statistics (pp. 278-292). Palo Alto, California, Essays in Honour of Harold Hotelling, Stanford University Press.

Longino, J. T. (1989). Geographic variation and community structure in an ant-plant mutualism: Azteca and Cecropia in Costa Rica. Biotropica, 22(2), 126-132.

Longino, J. T. (1991a). Azteca ants in Cecropia trees: Taxonomy, colony structure, and behavior. In C. R. Huxley \& D. F. Cutler (Eds.), Ant-Plant Interactions (pp. 271-288). Oxford: Oxford Univ. Press.

Longino, J. T. (1991b). Taxonomy of the Cecropia inhabiting Azteca ants. Journal of Natural History, $25,1571-1602$.

Longino, J. T. (2007). A taxonomic review of the genus Azteca (Hymenoptera: Formicidae) in Costa Rica and a global revision of the aurita group. Zootaxa, 1491, 1-63.

Maschwitz, U., Fiala, B., Dumpert, K., Hashim, R., \& Sudhaus, W. (2016). Nematode associates and bacteria in ant-tree symbioses. Symbiosis, 69(1), 1-7.

Oliveira, K. N., Coley, P. D., Kursar, T. A., Kaminski, L. A., Moreira, M. Z., \& Campos, R. I. (2015). The effect of symbiotic ant colonies on plant growth: a test using an Azteca-Cecropia system. Journal PLOS One, 10(3), 1-13. DOI: 10.1371/journal.pone.0120351

Penn, O., Privman, E., Ashkenazy, H., Landan, G., Graur, D., \& Pupko, T. (2010). GUIDANCE: a web server for assessing alignment confidence scores. Nucleic Acids Research, 38, 15.

Poinar, G. (2012). Nematode parasites and associates of ants: past and present. Journal Psyche, 25, 1-13.

Rickson, F. R. (1971). Glycogen plastids in Müllerian body cells of Cecropia peltata a higher green plant. Science, 173, 344-347.

Rickson, F. R. (1976). Anatomical development of the leaf trichilium and Müllerian bodies of Cecropia peltata. American Journal of Botany, 63, 1266-1271.

Rocha, C. F., \& Bergallo, H. G. (1992). Bigger ant colonies reduce herbivory and herbivore residence time on leaves of an ant-plant: Azteca muelleri vs. Coelomera furiicornis on Cecropia pachystachya. Oecologia, 91, 249-252.

Ronquist, F., \& Huelsenbeck, J. (2003). MrBayes 3: Bayesian phylogenetic inference under mixed models. Bioinformatics, 19, 1572-1574. 
Sagers, C. L., Ginger, S. M., \& Evans, R. D. (2000). Carbon and nitrogen isotopes trace nutrient exchange in an ant-plant mutualism. Oecologia, 123, 582-586.

Schupp, E. W. (1986). Azteca protection of Cecropia: ant occupation benefits juvenile trees. Oecologia, $70,379-385$.

Seinhorst, J. W. (1959). A rapid method for the transfer of nematodes from fixative to anhydrous glycerin. Nematologica, 4, 67-69.

Shapiro, S. S., \& Wilk, M. B. (1965). An analysis of variance test for normality (complete samples). Biometrika, $52,591-611$.

Sidney, S., \& Castellan, N. (1988). Nonparametric Statistics for the Behavioral Sciences. Second edition. New York: McGraw-Hill.

Simpson, B. B., Helfgott, D. M., Weeks, A., \& Larkin, L. (2004). Species relationships in Krameria (Krameriaceae) based on ITS sequences and morphology: implications for character utility and biogeography. Systematic Botany, 29, 97-108.

Stock, P., Campbell, J. F., \& Nadler, S. (2001). Phylogeny of Steinernema travassos, 1927 (Cephalobina:
Steinernematidae) inferred from ribosomal DNA sequences and morphological characters. Journal of Parasitology, 87, 877-89.

Tamura, K., Dudley, J., \& Kumar, S. (2007). MEGA6: Molecular Evolutionary Genetics Analysis (MEGA) software version 6.0. Molecular Biology and Evolution, 24, 1596-1599.

Trimble, S. T., \& Sagers, C. L. (2004). Differential host use in two highly specialized ant-plant associations: evidence from stable isotopes. Oecologia, 138, 74-82.

Valverde, J. P., \& Hanson, P. (2011). Parenchyma: a neglected plant tissue in the Cecropia/ant mutualism. Symbiosis, 55, 47-51.

Weng, J., Nishida, K., Hanson, P., \& LaPierre, L. (2007). Biology of Lissoderes Champion (Coleoptera, Curculionidae) in Cecropia saplings inhabited by Azteca ants. Journal of Natural History, 41(25-28), 1679-1695.

Webster, R., Allison, V. F., Ubelaker, J. E., \& Riddle, J. M. (1971) Glycerine preparation of nematode material for scanning electron microscopy. Texas Reports on Biology, 29, 433-434. 